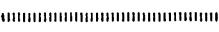
解説

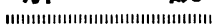

\section{Agrochemistry and Biology Series}

\section{アラキドン酸カスケードとその周辺}

横田一成

島根大学農学部生物資源科学科生物資源化学講座

(平成 4 年 8 月 20 日受理)

\title{
Arachidonate Cascade and Related Recent Studies
}

\author{
Kazushige Yokota \\ Department of Bioresource Chemistry, Faculty of Agriculture, \\ Shimane University, Nishikawats.i-cio, Matsue 690, Japan
}

\section{は じめに}

プロスタグランジン $(\mathrm{PG})$ とその関連化合物は，いず れも哺乳動物で発見された一群の生理活性脂質である.

PG の発見は, 1930 年代にヒトの精液中のアルコール 可溶性の脂質性分子が子宮平滑筋を収縮することに始ま るが，その当時，その生理活性物質は，前立腺 (prostate gland) でつくられるものと思われて PG (prostaglandin) と命名された. その後の研究で, 前立腺で はなくて実際は精囊腺でつくられることがわかったが， その当時の名前が今も残っている. また，その中の成分 も単一品ではなくて混合物であった. PG の生合成に関 する研究から，これらが，栄養成分で必須脂肪酸のアラ キドン酸に由来することが明らかにされた. その後, 現 在までに PGにさらに多くの種類が見いだされ，生合 成経路や化学構造の違う別のグループの物質も発見, 追 加されて膨大の数のものが PGの仲間に加わった。狭 義の意味での PG は，五員環構造をもつグループの化 合物をいうが，広い意味では PG という名称は，アラ キドン酸に由来する一群の生理活性物質の代名詞となっ ている. PGを呼ぶ場合, 単に PG 類あるいはプロスタ ノイド (prostanoid) というが，アラキドン酸由来の代 謝物をエイコサノイド (eicosanoid), あるいは，炭素数 20 個の 多価不飽和脂肪酸が 酵素的に酸素添加反応を受 けてつくられることから，オキシエイコサノイド (oxyeicosanoid) とも呼ぶ.

PG 類は，一般に pM から nM という極微量で特定の 臓器, 組織, 細胞に作用して各細胞機能の働きを促進し
たり抑制したりする、標的となる細胞の違いによって特 異な作用を示すことになる. PG 類の作用の特徴は, イ ンシュリンやステロイドホルモンなどのように特定の組 織でつくられたものが，血液中を巡って標的藏器の特定 の細胞の受容体に作用する循環ホルモンとは違ってい る.すなわち，FG 類は，刺激応答を受けていない状態 では，血液循環中や細胞内に存在していない。ホルモン や神経伝達物質の作用を受けるととの都度, 生体膜りン 脂質からホスホリパーゼの作用によりアラキドン酸が遊 離し，この遊離アラキドン酸に種々のリポキシゲナーゼ が作用して特異的に酸素添加反応が起こる.ささらに代謝 されて活性体がつくられる.このようなエイコサノイド の生合成経路は，あたかも，アラキドン酸から滝が流れ るがごとく反応が分岐して進むということでアラキドン 酸カスケードと呼ばれる. このカスケード反応でつくら れた生理活性物質は, 細胞外に出て同種の細胞や異種の 細胞に作用した後, 役割を終えると局所あるいは血液中 に出て循環する間に化学的にまたは酵素作用で速やかに 不活性化される。このような性質から局所ホルモン（オ ータコイド）と呼ばれる.エイコサノイドの生物活性 は，動物の組織や細胞の違いにより同じ化合物でも多彩 な効果を示す. 生物活性の全体像については文献 1)を 参照されたい. 最近の研究によると, ある種のエイコサ ノイド類は, 細胞外からの作用以外に細胞内からセカン ドメッセンジャーとして細胞内受容体 (イオンチャネル) に作用するともいわれ，多機能性を示す脂質メディエー ターといえる. 


\section{膜リン脂質からのアラキドン酸の遊離反応}

アラキドン酸は，動物細胞膜のリン脂質の $s n-2$ 位に ほぼ選択的に取り込まれており，細胞内に遊離の形とし ては存在していない（図 1)。細胞情報伝達物質の作用 で細胞応答が起こると，アラキドン酸遊離に関わるホス ホリパーゼ類が活性化される．膜りン脂質からのアラキ ドン酸の遊離機構については血小板や白血球などの血球 系細胞を主に用いて検討されてきた，その代表的経路と して $s n-2$ に結合したアラキドン酸に直接働いて加水分 解するホスホリパーゼ $\mathrm{A}_{2}$ がある。 それに対して，ポリ ホスホイノシチド（イノシトールリン脂質）に特異的に 作用するホスホリパーゼ Cが良く知られている。多く の細胞では, 反応刺激を受けて速やかに数秒や数分のオ 一ダーで活性化されるのはホスホリパーゼ C であり, 本酵素は，ホスファチジルイノシトール (PI)-4,5-二リ ン酸(トリホスホイノシチド)のリン酸ジエステル部分を 加水分解して，1，2-ジグリセリドとイノシトール 1,4,5三リン酸を生成する，血小板での実験から，さらに，1，
2-ジグリセリドに，ジグリセリドリパーゼが㗢いて，ま ず，C-1 位の脂肪酸が遊離し，アラキドン酸が結合した 2-モノグリセリドが生成する，さらに別のモノグリセリ ドリパーゼが働いてアラキドン酸が遊離するという経路 が知られている．これらのホスホリパーゼ類の関与する 反応は，他の細胞情報伝達反応系との関わりでも大変注 目されている.ポリホスホイノシチド由来の加水分解物 の 1,2-ジグリセリドは，プロテインキナーゼ C の活性 化物質の 1 つとなっている.さらに，もう一方のイノシ トール-1,4,5-三リン酸は，小胞体内に貯留された $\mathrm{Ca}^{2+}$ を放出して細胞内へ動員し，それぞれセカンドメッセン ジャーとして刺激に応答した細胞内の情報伝達機構に重 要な役割を果たすことは有名である。また 1-アルキルー 2-アシル-snーグリセロ-3-ホスホコリンからホスホリパ 一ゼ $\mathrm{A}_{2}$ でアラキドン酸が遊離したとき，アセチル基が $s n-2$ 位に取り込まれて血小板活性化因子 (PAF) が生成 する.

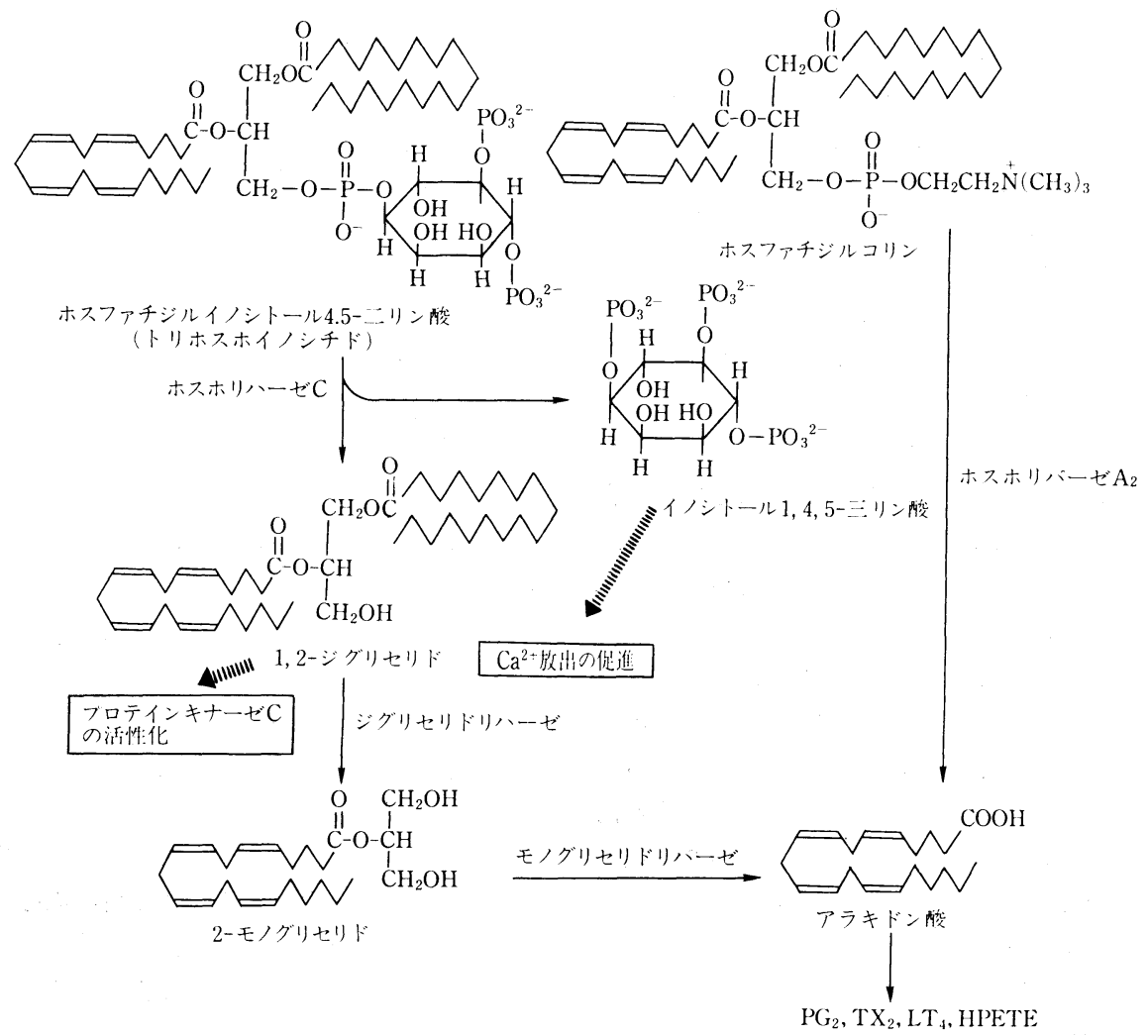

図 1 膜リン脂質からのアラキドン酸の遊離反応 


\section{シクロオキシゲナーゼ系生合成経路}

$\mathrm{PG}$ やトロンボキサン (TX) を生成する際, 最初にア ラキドン酸に作用して分子状酸素を取り込む酵素は，脂 肪酸シクロオキシゲナーゼである. 本酵素は, PG エン ドペルオキシド合成酵素あるいは PGH 合成酵素とも 呼ばれる。この酵素は 2 分子の酸素分子を取り込んで， 9,11-エンドペルオキシドと 15-ヒドロペルオキシドを もつ $\mathrm{PGG}_{2}$ を生成する特殊なりポキシゲナーゼである. さらに， $\mathrm{PGG}_{2}$ の 15 -ヒドロペルオキシドは $\mathrm{PG}$ ヒドロ ペルオキシダーゼにより還元されて水酸基となり, $\mathrm{PGG}_{2}$ は $\mathrm{PGH}_{2}$ に変換される。.これらの 2 つの反応を 1 つの酵素蛋白質が触媒する. $\mathrm{PGH}_{2}$ は, 種々の $\mathrm{PG}$ 類 と $\mathrm{TX}$ の生合成酵素の基質となる重要な中間物質であ る. 9-ケト，11-ヒドロキシ体の $\mathrm{PGE}_{2}$ をつく $\mathrm{PGE}$ 合成酵素は, ヒツジなどの精囊腺から単離されているが， 補酵素としてグルタチオンを要求する， $\mathrm{PGA}_{2}, \mathrm{PGB}_{2}$ そして $\mathrm{PGC}_{2}$ は，大部分 $\mathrm{PGE}_{2}$ が化学的に変化したも
のである. $\mathrm{PGE}_{2}$ は，腎臟での利尿作用やレニン分泌促 進，胃液分泌抑制，免疫機能抑制，骨吸収促進などの多 彩な機能を示す． $\mathrm{PGE}_{2}$ とその誘導体は，慢性動脈閉塞 さらに振動病などにおける血行改善, 術後腸管麻瘏，胃 潰煬などの治療薬として臨床的に使われている．9-七ド ロキシ，11ーケト体の $\mathrm{PGD}_{2}$ をつくる $\mathrm{PGD}$ 合成醭素 は，ラット脳や脾臓の可溶性画分から精製されている. $\mathrm{PGD}_{2}$ は，脳組織に見いだされ体温の低下や徐波睡眠の 誘導に関わるとされる. $\mathrm{PGD}_{2}$ の分解物の $\mathrm{PGJ}_{2}$ と $\Delta^{12}-\mathrm{PG} \mathrm{J}_{2}$ は，腫煌細胞の增殖を抑制する， $\mathrm{PGF}_{2 \alpha}$ の 生合成経路には， $\mathrm{PGH}_{2} ， \mathrm{PGD}_{2}$ そして $\mathrm{PGE}_{2}$ が，そ れぞれ還元される 3 つの経路が知られている. 最近の研 究によると，ヒト肝藏やウシ肺から NADPHを要求す る $\mathrm{PGD}_{2}-11$-ケト還元醭素が単離されており，その反 応生成物は, $\mathrm{PGF}_{2 \alpha}$ ではなくて11-エピ- $\mathrm{PGF}_{2 \alpha}(9 \alpha$, $\left.11 \beta-\mathrm{PGF}_{2}\right)$ である. 同じ酵素が $\mathrm{PGH}_{2}$ を基質とすると $\mathrm{PGF}_{2 \alpha}$ が生成するという. $\mathrm{PGF}_{2 \alpha}$ は，子宮収縮や黄体 退行を引き起こすので分婏誘発や娃娠中期における治療

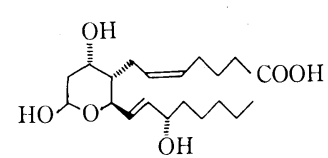

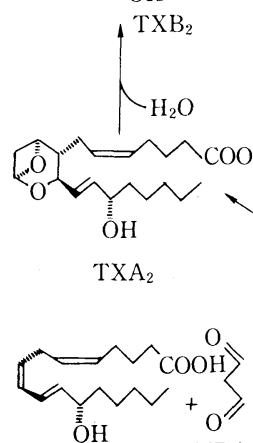
HHT MDA

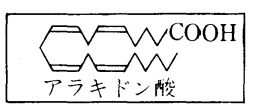

アフキドン怡

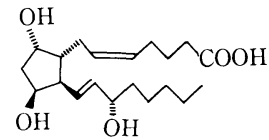

$11-エ ヒ-\mathrm{PGF}_{2 \alpha}$

$\left(9 \alpha, 11 \beta-\mathrm{PGF}_{2}\right)$

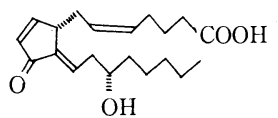

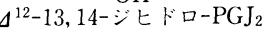

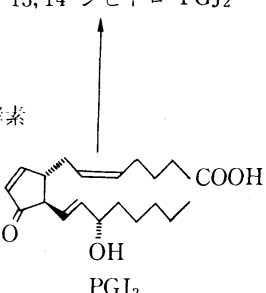

$\mathrm{PGD}$ 公成䤑素
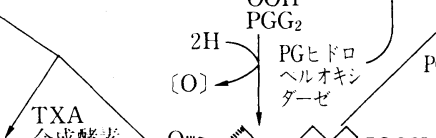

$\mathrm{OH}$

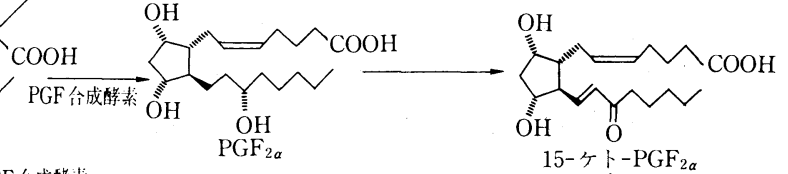
$\mathrm{OH}_{2}$<smiles>CC(O)C=CC1CO1</smiles>

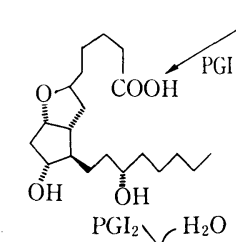
$\mathrm{H}_{2}$ PGF公成醉系

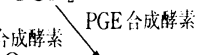
垈成醉素

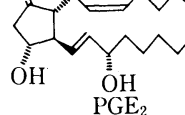

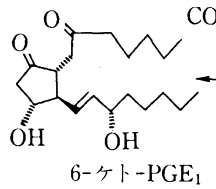
$\mathrm{COOH} \quad \mathrm{O} Y \mathrm{COOH}$

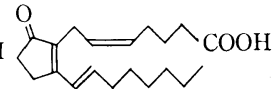
$\mathrm{OH}$<smiles>CCCCCC(=O)CCC1=CCC(O)CC(C)C1CCC(=O)O</smiles>
13,14-ジヒドロ-15-ケト-PGF $2 a$<smiles>CCCCC(CCC(=O)CCCCC(=O)O)C1C(O)CC(O)C1O</smiles>
$5 \alpha, 7 \alpha$-ジヒドロキシー11-ケトー テトラノルプスター1, 16ジカルボン酸 ( $\mathrm{PGF}_{a}$ 主要好中代謝物)

図 2 シクロオキシゲナーゼ系生合成経路 
的流産の臨床薬となっている. $\mathrm{PGH}_{2}$ に㗢いて 6,9-エ ポキシドおよび $11 \alpha$-水酸基をもつ $\mathrm{PGI}_{2}$ を生成する PGI 合成酵素は，ウシの大動脈で精製されて，へム酵 素であることが示されている． $\mathrm{PGI}_{2}$ は，血管内皮細胞 でつくられ，血管拡張作用を示し血小板凝集を抑制し て, 血液循環を調節する重要な因子となっている， $\mathrm{PGI}_{2}$ は中性の水溶液中で半減期が $5 \sim 10$ 分といわれており， 安定分解産物で不活性な 6-ケト-PGF $1 \alpha$ に変換される. TXA 合成酵素は血小板で活性が強く, シトクローム P450 様の一ム酵素といわ㧈ている. $\mathrm{TXA}_{2}$ は，強力な 動脈収縮作用と血小板凝集作用を示し止血を促進する. 一方で，動脈硬化巣でのように血栓を形成して虚血性病 変を引き起こす，TXA 酵素反応液中での半減期が 30 秒である. 速やかに加水 分解し生物活性をもたない $\mathrm{TXB}_{2}$ になる。一般に生理 的役割を果たした PGや TXは，血液循環で代謝され て生物活性を失う．その経路として 15 位の水酸基が脱 水素化されてヶト基に，さらに $\Delta 13$ 位の還元飽和化， さらに $\beta$ と $\omega$ の酸化という反応が知られている．血液 中や尿中の安定代謝産物は, 生理や病理条件でのエイコ サノイドの測定に使われる.

\section{他のリポキシゲナーゼ系生合成経路}

\section{5-リポキシゲナーゼ系生合成経路}

種々の動物の白血球に 5-リポキシゲナーゼ活性が 強 い.アラキドン酸に 5-リポキシゲナーゼが作用して酸 素添加すると 5-オキシゲナーゼ活性で 5-ヒドロペルオ キシエイコサテトラエン酸(HPETE)が生成する.さら に本酵素が 5-HPETEに作用して 5-ヒドロペルオキシ 基の酸素と酸素の間を開裂してロイコトリエン (LT) $\mathrm{A}_{4}$ をつくることが示されている１つの酵素蛋白がこれら の反応を触媒していることは精製䣼素や cDNA クロー ンを発現した醅素標品で確認されている. LTA 4 は化学 的には安定ではなく, 自然に加水分解しやすいが，別の LT 合成醉素の関与で生理活性をもつ LT 類がつくられ る. 1 つは, LTA 水解酵素により $\mathrm{LTA}_{4}$ の 5,6-エポ キシドが開裂した 5,12 -ジヒドロキシ酸の $\mathrm{LTB}_{4}$ であ る. $\mathrm{LTB}_{4}$ は多核白血球の走化性と運動性を促進し, さ らに凝集やリソソーム䣼素の遊離を引き起こす。一方, $\mathrm{LTA}_{4}$ に LTC 合成醉素が反応すると， $\mathrm{LTA}_{4}$ の酸素原 子は 5-水酸基となり，C-6にグルタチオンが，そのシ ステイン残基の硫黄原子を介してチオエーテル結合で入 り $\mathrm{LTC}_{4}$ が生成する. $\mathrm{LTC}_{4}$ のペプチド部分は $\gamma$-グル タミルトランスペプチダーゼにより，さらに代謝されて グルタミン酸残基がはずれ LTD4 となり,さらにジペプ
チダーゼでグリシン残基がはずれて $\mathrm{LTE}_{4}$ になるが， これに再度 $\gamma$-グルタミルトランスペプチダーゼが作用 するとグルタチオンからグルタミン酸残基が取り込まれ て $\mathrm{LTF}_{4}$ となる. $\mathrm{LTC}_{4}$ と $\mathrm{LTD}_{4}$ は，アナフィラキシ 一（即時型アレルギー）で放出される気管収縮物質の本 体として発見されている，また，血管の透過性を高め血 液浸出を著しく増強する。

\section{12-リポキシゲナーゼ系生合成経路}

ヒトやウシの血小板やブタの白血球などに見いだされ ている，両者の酵素の反応特性は，同じではなくて免度 学的性質や基質に対する反応性も異なる。ブタの白血球 の精製醅素を使った実験で，本醅素は，アラキドン酸に 酸素添加して 12-HPETE を生成するほかに，15HPETE と反応して $8 S$-オキシゲナーゼ活性と $14 R-$ オキシゲナーゼ活性を示すとともに，15-ヒドロペルオ キシドを 14，15-エポキシドに変換して 14, 15-LTA 4 を生成する. 8 位あるいは 10 位に水酸基をもつ 11,12 エポキシド化合物の $\mathrm{HXA}_{3}$ および $\mathrm{B}_{3}$ は, 12-HPETE からつくられるが, 非酵素的反応と考光られている，12HPETEは，アラキドン酸やコラーゲンによる血小板 凝集を阻害し，また，12-HETEは血管中膜平滑筋細 胞を強く遊走させる. $\mathrm{HXA}_{3}$ には膵臓でのインシュリ ン分泌の促進作用がある.

\section{15ーリポキシゲナーゼ系生合成経路}

ヒトやウサギの網状赤血球で活性が強い. アラキドン 酸に精製酵素を反応させると酸素添加反応が起こり, 15-HPTETE がつくられるが，一部の 反応について は，12-リポキシゲナーゼと同じような反応性を示す. 15-リポキシゲナーゼと 5-リポキシゲナーゼの二重の酸 素添加反応で $5 S, 15 S$-diHETEが生成し, さらに変換 されて共役テトラエン構造をもつリポキシン (LX)A と LXB ならびにそれらの異性体がつくられる。このとき に，5-，12-，15-リポキシゲナーゼのもつオキシゲナー ゼ活性による好気反応と， LTA 合成䤃素活性による嫌 気反応が関与する．LX は白血球を活性化し，ナチュラ ルキラー細胞活性を抑制するという。

\section{4. シトクローム P-450 によるアラキドン酸代謝}

肝藏, 腎藏, 副腎などの諸藏器のミクロソームやミト コンドリアに含まれるへム蛋白質のシトクローム P450 は, 酸素添加醅素（モノオキシゲナーゼ）として, 酸素分子と $\mathrm{NADPH}$ を消費つつ，アラキドン酸や $\mathrm{PG}$ 類の $\omega$ (C-20 位) あるいは $\omega-1$ (C-19 位) を水酸化, さらにカルボキシル基まで酸化する，また，アラキドン 酸から 5-, 8-, 9-, 11-, 12- および 15-の各種のモノヒ ドロキシ脂肪酸がつくられる. 皮膚病の尋常性乾痽の病 


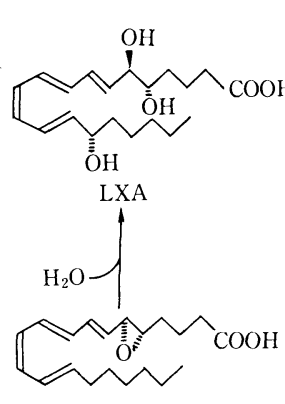

15S-ヒドロヘルオキシ-LTA

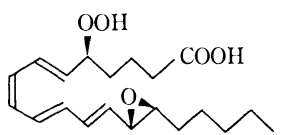

$5 S$ ーヒドロベルオキシ-14, 15- $\mathrm{LTA}_{4}$<smiles>CCCCC[C@H](O)[C@@H](O)[C@@H](O)CCCC(=O)O</smiles>

$5 S, 14 R, 15 S$-triHPETE<smiles>CCCCCC(O)C(O)C(O)/C=C/C=C\C=C\C(=O)CCCC(=O)O</smiles>

LXB

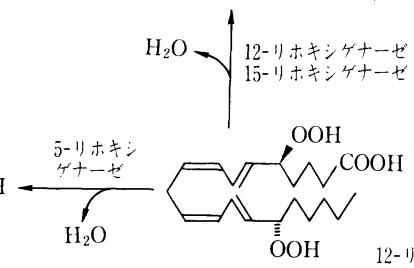

5, 15-diHPETE

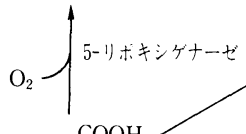

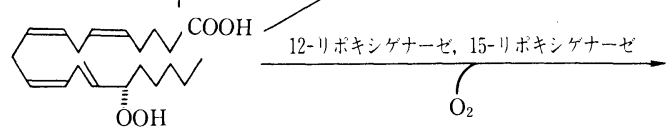

5-HPETE

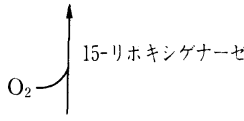

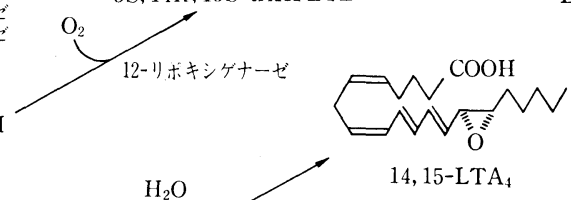

$\mathrm{H}_{2} \mathrm{O}$<smiles>CCCCC[C@H](O)/C=C/C=C\C=C\[C@H](O)C/C=C\CCCC(=O)O</smiles>

$8 S, 15 S$-diHPETE

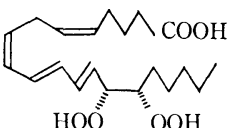

$14 R, 15 S$-diHPETE

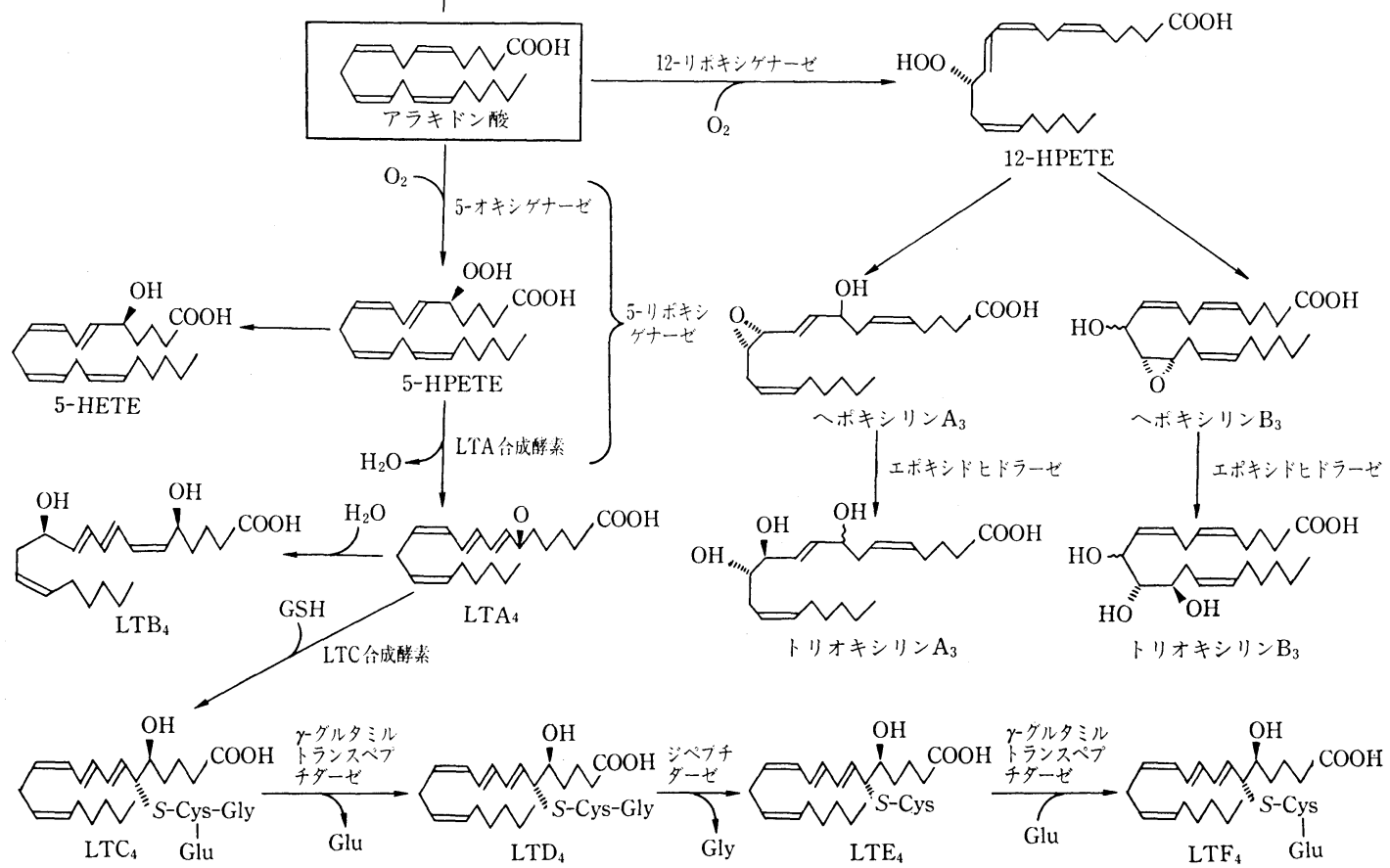

図 3 リポキシゲナーゼ系生合成経路

変部位で多くつくられる 12-HETEは，12S-ではなく $12 R$-HETE である.ささらに，アラキドン酸の 4 つの二 重結合部分が，それぞれエポキシ化されたエポキシトリ エン酸 (EET) が生成するが，下垂体前葉での LH 分泌 が 5, 6-EET で促進されるという。

\section{アラキドン酸カスケードの調節}

アラキドン酸カスケードのマップを見ると，母体のア ラキドン酸から複雑に分岐した経路となって非常に多く のものがつくられる.しかし，これらは，記載された化 
合物がぞの組織にも存在するという意味ではない，各臓 器や細胞によってつくられるものは限られている。 ま た，種々の代謝調節因子の作用でアラキドン酸カスケー ド関連の生合成酵素が de novo で誘導される例も多く発 見されている．分岐したアラキドン酸カスケードから種 種の生理活性物質がつくられ，生理的役割や病態の進行 に重要な役割を果たすことから，人為的に薬物あるいは 食慨因子によって調節する試みが精力的に行われてい る.カスケード反応に作用して阻害活性を示す物質の検 索により既知の薬物がカスケードの特定の反応を阻害す ることが明らかにされている(図 4)。ホスホリパーゼに よる膜リン脂質からのアラキドン酸の遊離反応は，特に 急性の刺激応答を示す血小板や白血球の上うな血球系細 胞では特に PG や LT の生合成の律速段階とされてい る.いずれにせよ，この反応経路を抑制すればアラキド ン酸カスケードの全てが阻害されることになる。ホスホ リパーゼ $\mathrm{A}_{2}$ 阻害剤として良く知られているのは，抗マ ラリヤ薬のメパクリンや局所麻酔薬のクロルプロマジン である。ささらに強力な阻害活性を示すのは，デキサメ夕 ゾンやヒドロコルチゾンなどのグルココルチコイドであ る。これらのステロイド性抗炎症薬自体は，ホスホリパ 一ゼ $\mathrm{A}_{2}$ 阻害活性を示さず，阻害活性を示す蛋白質を生 合成する. 種々の 細胞, 組織中に存在することがわか り, 総称的にリポコルチンと呼ばれている. 当初, ホス ホリパーゼ $\mathrm{A}_{2}$ との相互作用が阻害機構として考兄られ ていたが，現在，これは否定的で， $\mathrm{Ca}^{2+}$ とリン脂質 とにリポコルチンが直接, 結合していわば立体障害で ホスホリパーゼ類の作用を阻害するものと見なされてい る.

シクロオキシゲナーゼを特異的に阻害することで有名 なのは，アスピリンやインドメタシンのような抗炎症剤 である．アスピリン(アセチルサリチル酸)は，特定のセ リン残基をアセチル化して不可逆的に阻害する．TXA のもつ強力な血小板凝集促進作用，血管平滑筋収縮作用 から心臓や脳の虚血, 藏器移植における拒絶反応, エン ドトキシンショック，気管支喘息などの病態の進行にお ける $\mathrm{TXA}_{2}$ の役割を考えて，TXA 合成酵素の特異的 阻害剤の開発が活発に進められ，イミダゾール誘導体の OKY-046 やダゾキシベンなどが開発された，PGI 2 は 生体内での血栓の生成防止に大きな役割を果たすと考兄 られ， $\mathrm{TXA}_{2}$ とは逆に $\mathrm{PGI}_{2}$ 産生を促進するような物 質も検討されて種々のホルモン類が促進物質となること がわかった，LTが炎症やアレルギー発生および促進に 深く関わることから，5-リポキシゲナーゼを特異的に阻 害する薬物の開発が注目されている。ベンゾキノン誘導
体の AA-861 の開発がもっともすすんでいるが，フラ ボノイド化合物のサーシリオールとその誘導体， $\mathrm{LTA}_{4}$ 類似体の 5，6-メ夕ノ- $\mathrm{LTA}_{4}$ ，中国産の生薬の 紅足高の 成分のカフェイン酸を誘導化した TMK-777なぞも検 討されている，BW755C は，シクロオキシゲナーゼも 他のリポキシゲナーゼも阻害する非特異的阻害剤として 研究上しばしば使用される。

$n-3$ 系列の必須脂肪酸で栄養成分のエイコサペンタエ ン酸 $(\mathrm{EPA})$ とドコサへキサエン酸 (DHA) は，魚油に 多く含まれている，EPA 摂取による動脈効果予防との 関連が注目されるようになったのは，グリーンランドの エスキモーの疫学調査である。エスキモーは，白人など と比べて心筋梗塞や脳梗塞などの 動脈硬化になりにく く，むしろ出血傾向がある，その原因が，食事に由来す る魚油の成分の EPA が血小板の凝集や粘着を阻害する ためと推定された．実際，エスキモーの血中脂肪酸では デンマーク人に比べて，アラキドン酸含有量が少なく, EPA DHA が多いことが確認されている．モデル奏 験で， EPA はアラキドン酸の $\mathrm{TXA}_{2}$ への変換を阻害 すること， EPA からつくられる $\mathrm{TXA}_{3}$ の血小板凝集 作用は TXA に比べて弱いこと,一方の $\mathrm{PGI}_{3}$ は $\mathrm{PGI}_{2}$ と同じ程度の血小板凝集抑制効果を示すことなどが確認 されている.もちろん，エスキモー特有の体質や遗伝特 性も指摘されていろいろ議論のあるところもある。

\section{アラキドン酸カスケードの 分子生物学的アプローチ}

アラキドン酸カスケードに関わる生合成醳素について 最近の遺伝子工学的手法を用いた研究が進んでいる22. ヒッジ精囊腺のシクロオキシゲナーゼは，23 あるいは 24 残基のシグナルペプチドに続く 576 残基の成熟酵素 である、N-末端側にマウス上皮生長因子と類似した配 列が存在し，C-末端側に他のペルオキシダーゼと相同 性を示す部分がある.アスピリンで 506 番目のセリンが アセチル化されるが，このセりンを部位特異的変異法で アラニンに変换しても酵素活性があるという．リポキシ ゲナーゼ類については，動物のものでは 5-，12-および 15-リポキシゲナーゼが，植物では，ダイズやエンドウ の cDNA クローンが単離され，それらの酵素の 1 次構 造が明らかにされて，䣼素の活性部位に関するアミノ酸 が同定されつつある．LT の生合成に関与する 5-リポ キシゲナーゼの成熟型酵素は，673 個のアミノ酸からな る細胞質可溶性の酵素でシグナルペプチドをもたない． cDNA を発現ベクターに組み込んで得られた酵素標品 は，5-オキシゲナーゼ活性と $\mathrm{LTA}_{4}$ 合成酵素活性の両 


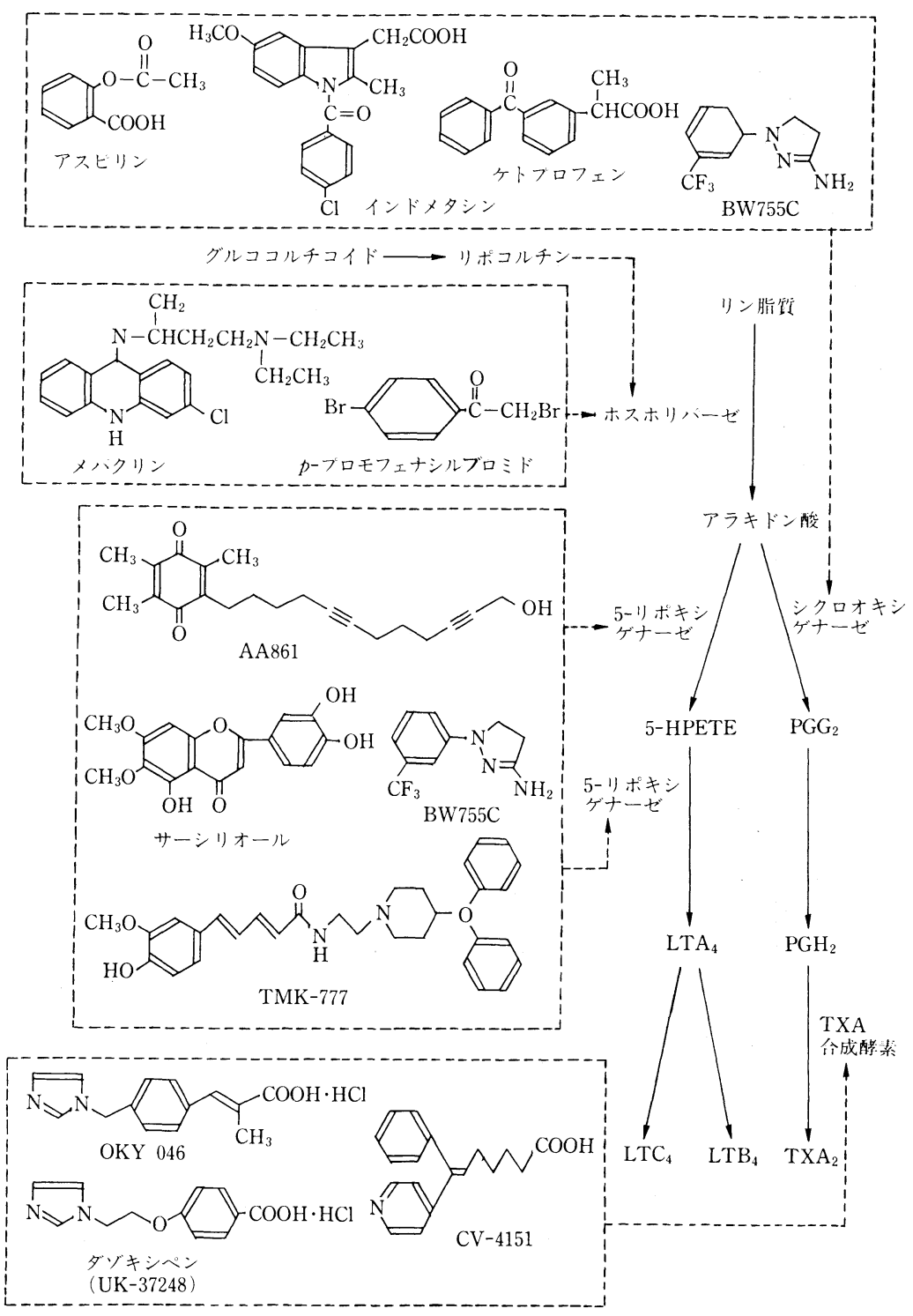

図 4 アラキドン酸カスケードの特異的阻害剂

方の活性をもつことが確認されている，12-リポキシゲ ナーゼには, 白血球型と血小板型の 2 種類の酵素が存在 し，いずれも成熟酵素は 662 のアミノ酸から、構成され ている. CDNA クローンの解析から, ブタ白血球の 12 リポキシゲナーゼは，ヒト血小板のものよりもむしろ， 網状赤血球の 15-リポキシゲナーゼと相同性が高いこと が示されている. ブタの 12-リポキシゲナーゼのバリン 419 をメチオニンに置換すると著しく 15-リポキシゲナ 一ゼ産物が増加するという，一方，15-リポキシゲナー ゼの cDNA は, ウサギやヒトの網状赤血球から単離さ
れ，成熟酵素はウサギで 662 個，ヒトで 661 個のアミ ノ酸からなる.ヒトの 15-リポキシゲナーゼのメチオニ ン 418 をバリンに置換すると，12-リポキシゲナーゼ活 性を示すようになる. 植物りポキシゲナーゼでもダイズ やエンドウの種子のアイソザイム酵素の cDNA クロー ンが単離されアミノ酸配列が決定されて，動物，植物を 合わせた酵素の活性部位の推定が試みられている．各酵 素のアミノ酸配列を比較すると，酵素の中央部に His$\mathrm{X}_{4}$-His- $\mathrm{X}_{4}$-His- $\mathrm{X}_{17}$-His- $\mathrm{X}_{8}$-His（X は任意のアミノ 酸）の配列がよく保存されている。この部分が非へム鉄 


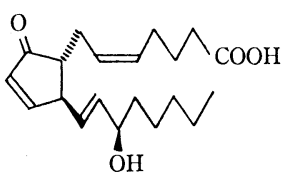

15-エピ-PGA 2

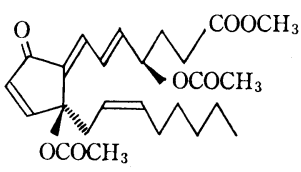

クラブロン II

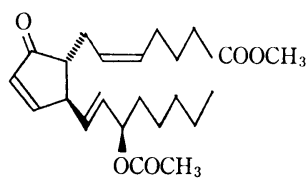

15-エピ-PGA $\mathrm{P}_{2}$ ジエステル $\mathrm{OCOCH}_{3}$

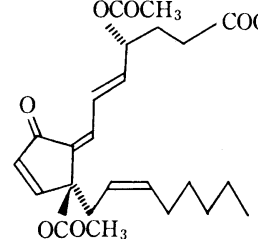

クラブロン III

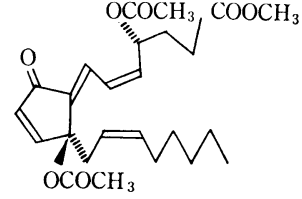

クラブロン I

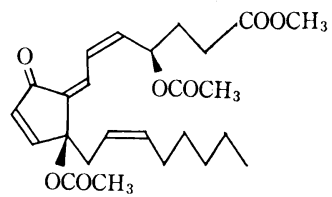

クラブロン $\mathrm{V}$

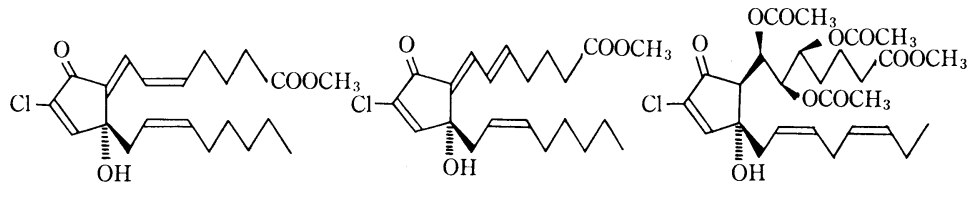

クロロブロン I

クロロブロン II

ブナグランジン I

OH

プナグランジン II

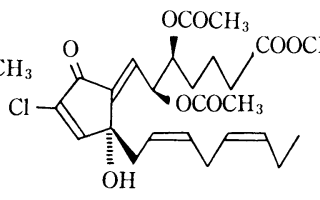

ブナグランジン III

(a) 海磼ブロスタノイド

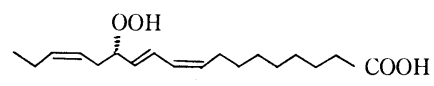

13-ヒドロベルオキシー $\alpha$ リリノンン县
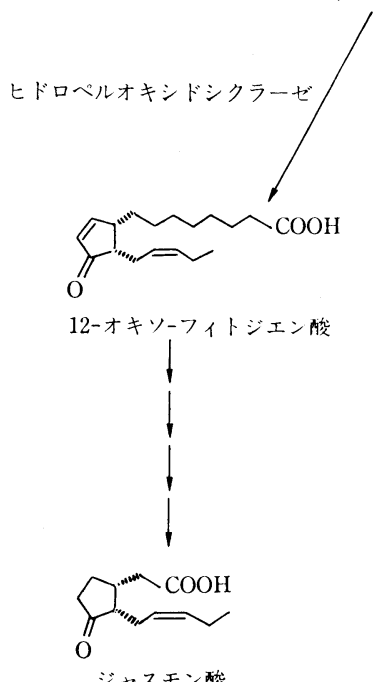

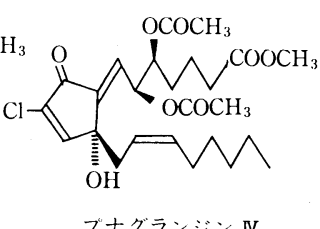

ブナグランジン $\mathrm{N}$
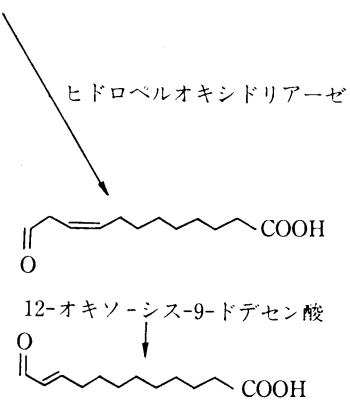

12-オキソートランスードデセン般

(トラウマチン)

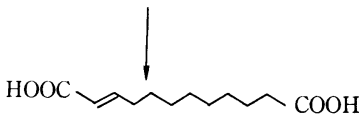

トランスー2-ドデセンージカルボン酸

(トラウマチン酸)

(b) 㭻物りポキシゲナーゼ代謝应物

図 5 哺乳動物以外の生物がつくる PG 様生理活性物質 
の結合部位と考えられている.

\section{細胞レベル，分子レベルでの エイコサノイドの作用機構}

エイコサノイドは，脂質であるが酸化されて親水性の 性質をもつため，細胞の外から中には入りにくい。した がってPG 類が 細胞に 働きかけて生物活性を発現する には細胞表首に受容体が必要である ${ }^{3)}$ 。薬理学的研究で それぞれに特有の受容体が存在し，さらにそれぞれの受 容体にサブタイプ種が存在する．受容体蛋白質を精製す る武みが行われていたが，結合活性が不安定であること や蛋白含有量が極めて少ないことから精製はきわめて困 難であった，最近，ヒト血小板の $\mathrm{TXA}_{2} / \mathrm{PGH}_{2}$ 受容体 がアンタゴニストの S-145 という化合物を用いて電気 泳動的に均一になるをで精製され，CDNA クローンが 単離された ${ }^{4)}$. 受容体蛋白質は，343のアミノ酸残基か らなり，7つの疎水性領域をもつロドプシン型の蛋白質 で，GTP 結合蛋白質に連関する受容体之考えられてい る.ささらにこの cDNA プローブを用いてマウスから $\mathrm{TX}$ 受容体と $\mathrm{PGE}_{2}$ 受容体 1 つのサブタイプ種のクロ ーニングが行なわれた．これらは，互いに相同性を示す ことから1つのファミリーを形成しているものと見なさ れる. 今後, 1 つのエイコサノイド種についてどのぐら いの種類のサブタイプ種が存在するのかが明らかにされ るものと期待される．PG 類の生成系と連関してつくら れる PAFの受容体もアフリカッメガエルの卵母細胞の 発現クローニング法でモルモット肺の PAF 受容体が単 離され，さらにヒト白血球の受容体も得られて構造が決 定されている，両受容体蛋白質とも，GTP 結合蛋白質 に連関した 7 回膜貫通型受容体であり，ホスホリパーゼ $\mathrm{C}$ および $\mathrm{A}_{2}$ を活性化する．最近，エイコサノイドのあ る種のものが，直接，あるいは間接的にイオンチャネル に作用して細胞の内側で働く細胞内セカンドメッセンジ ヤーとなることが相次いで報告されている5). 軟体動物 のアメフラシの神経細胞のセロトニン特異的 $\mathrm{K}^{+}$チャネ ルを12-リポキシゲナーゼ産物の 12-HPETE が活性 化することが最初に報告され，その後，心筋細胞，平滑 筋細胞として神経細胞などでも別のりポキシゲナーゼ産 物によるイオンチャネル機能の調節が示されている.こ れからの新しい研究の方向のひとつとなると思われる. また，今後，アラキドン酸カスケードに関わる生合成醉 素や特異的受容体の分子生物学的研究が進展乙構造活性 相関が明らかにされるに従い，より特異性のある有用な 薬物がさらに開発されるものと期待される.

\section{哺乳動物以外の生物がつくる PG 様生理活性物質と役割}

PG 様の五員環構造をもつ PG 誘導体が，腔腸動物か ら見いだされている(図 5)。最初に，カリブ海に生息す る海洋腔腸動物の一種 Ploxaura homomalla から 15エピ-PGA 2 が単離された。 その後, 沖縄近海の八方サ ンゴの Clavularia viridis (ツッウミズタ) から， クラ ブロンあるいはクラビリデノンと名付けられた複数の化 合物と，ハロゲン化されたクロロブロンと呼ばれる化合 物が見いだされている．さらに八ワイの八方サンゴの Telesto riisei から, 塩素原子を含むプナグランジンが 単離されて化学構造が決定されている。これらの化合物 のらちアルキリデンシクロペンテノン構造をもつものの 抗腫場性が注目されている. 昆虫のコオロギ，イエバ エ，カイコなどでは，哺乳動物でつくられるものと同じ PGE P PGF シリーズの PG 類が見いだされている.

雄と雌の両方の頭部, 腹部, および生殖器と広く $\mathrm{PG}$ 合 成活性が検出されている、コオロギの場合，交尾したこ とのない雙が雄と交尾した後，雌で PG 合成能が検出さ れること，そして外から添加した $\mathrm{PGE}_{2}$ で産卵が起こ ることから，昆虫の生殖と PG との関連性が検討され ている. しかし，PG 効果の違いが昆虫の種間で指摘さ れており，統一的知見を得るには，さらに多くの検討が 必要である. 今後の研究の進展により, 別のエイコサ, イド種の発見や多様な生理的役割が解明されるもの之期 待される，一方，植物では，リポキシゲナーゼ経路で生 成する $\alpha$ リリノン酸の 13-ヒドロペルオキシドが，さ らに代謝されて生成するもののなかに，PG と同じょう にシクロペンテノン構造をもつ老化促進物質のジャスモ ン酸や創傷ホルモンと呼ばれるトラウマチンやトラウマ チン酸が知られている6) (図 5)，植物でも動物でのよう な細胞のシグナル伝達に関わるリポキシゲナーゼ産物由 来の生理活性物質を同定しようとする研究が盛んに行な われている.

\section{引用文 献}

1) 横田一成：ビタミンハンドブック 1 , 脂溶性ビタ ミン, 日本ビタミン学会編, 化学同人, p. 105, 1989

2) 田辺 忠-吉本谷博 - 藤 博幸: 蛋白質核酸酵素 37, 916 (1992)

3) 渡辺 毅：蛋白質核酸醉素 37，925 (1992)

4) Y. Sugimoto, T. Namba, A. Honda, Y. Hayashi, M. Negishi, A. Ichikawa \& S. Narumiya: $J$. Biol. Chem. 267, 6463 (1992)

5) 伊藤博之, 倉智嘉久：実験医学 9, 33 (1991)

6) J. N. Siedow: Annu. Rev. Plant Physiol. Mol. Biol. 42, 145 (1991) 